\title{
Giant symptomatic uterine fibroid: A rare case in Enugu, South East Nigeria
}

\section{Henry C Nnaji1 ${ }^{12 \star}$, Emmanuel 0 Udogu ${ }^{2}$, Eric E Asimadu ${ }^{1}$ and Emeka F Nnakenyi ${ }^{3}$}

Received: 08 January, 2020

Accepted: 04 March, 2020

Published: 05 March, 2020

*Corresponding author: Dr. Henry C Nnaji, Department of Obstetrics and Gynaecology, University of Nigeria Teaching Hospital, P.M.B. 01129, Enugu, Nigeria, Tel: +234803773 8502; E-mail:nnajihc@gmail.com

Keywords: Giant uterine fibroid; $14.5 \mathrm{kgs}$; Typical cells; Total abdominal hysterectomy

https://www.peertechz.com

\section{Check for updates}

${ }^{1}$ Department of Obstetrics and Gynaecology, University of Nigeria Teaching Hospital, P.M.B. 01129,

Enugu, Nigeria

${ }^{2}$ Royal Hospital, Enugu, Nigeria

${ }^{3}$ Department of Morbid Anatomy, University of Nigeria Teaching Hospital, Enugu, Nigeria

\begin{abstract}
Giant uterine fibroids are rare benign smooth muscle neoplasms of the uterus. They are gynaecological problems found among women of reproductive age that negatively impacts their health. Uterine fibroids are described as giant when the fibroid tissues weigh more than $11.4 \mathrm{~kg}$. This type of benign disease poses a great management challenge. Generally uterine fibroids are common gynaecological conditions among women of reproductive age and are asymtomatic in many women. Many are discovered incidentally on imaging on asymptomatic women but the symptomatic ones can cause abnormal uterine bleeding, pressure symptoms, bowel dysfunction and urinary symptoms.

We present a case of Giant Symptomatic Uterine Fibroid managed successfully in Enugu. The patient presented to a private specialist hospital in Enugu with complaints of gradual abdominal distension, weight loss and inability to move around easily. She had bowel symptom but there was no urinary symptoms. She was investigated and counselled on the diagnosis and management options. She consented to total abdominal hysterectomy which she had with good outcome.
\end{abstract}

\section{Case report}

This was a case of a 42year-old nulipara female who presented to a private specialist hospital in Enugu because of unusual but gradual abdominal distension. Her ultrasound diagnosis was of extensive intramural and subserosal myoma. Abdominal swelling was initially noticed around the lower abdomen but progressively increased in size involving the upper abdomen, that she later found it difficult to wear her regular clothes and move around easily.

There was associated constipation, but no nausea, vomiting or loss of appetite was reported. There was weight loss but no yellowish discoloration of eyes or urinary symptoms. There were no associated leg swelling, menstrual disorders, abnormal vaginal discharge or fever. The abdomen was grossly distended with masses arising from the pelvis that was about similar size of a 46-weeks pregnant woman. The masses were firm, nodular, mobile and non-tender with irregular outlines. There was no demonstrable ascites. Figure 1 below shows the patient's grossly distended abdomen before the surgery. An abdominopelvic ultrasound was performed and reported multiple, large uterine masses of varying sizes and shapes. These masses had

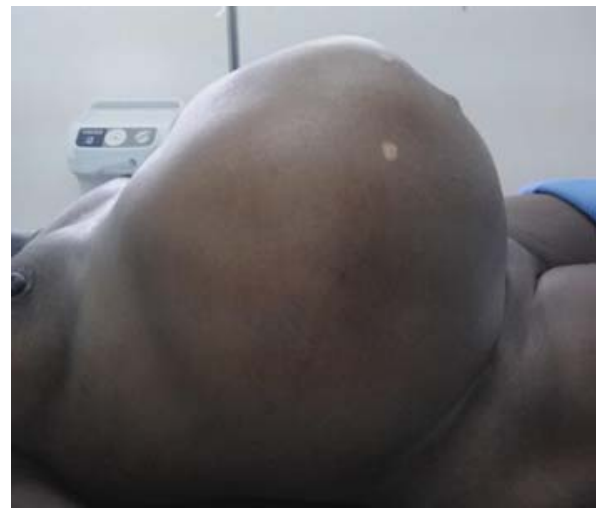

Figure 1: Grossly enlarged abdomen. 
typical myoma characteristic features that extended from the pelvic region to the epigastric region superiorly to both flanks laterally.

Fasting blood sugar and two hours post prandial were normal. Liver function test, CA 125, serum electrolyte, and full blood counts were within normal range. She was counseled on her condition, and she consented to total abdominal hysterectomy. Figure 2 shows the fibroid masses intraoperatively after an incision was made on the abdominal wall and peritoneum. This was performed three week after presentation with good outcome. She was transfused with two units of blood intra operatively, and she was commenced on intravenous fluid, antibiotics, and analgesics throughout the surgery and post-operative recovery. Her post-operative management was uneventful, and she was discharged on 6th post-operative day. She was followed up in the clinic for 6 months without any complaint and was hence discharged off clinic

Analysis of the fibroid mass indicated a weight of $14.5 \mathrm{~kg}$, and the microscopic examination revealed a benign mesenchymal proliferation composed of bundles of spindled cells. There were no atypical cells present, and histological diagnosis of leiomyoma was made by a pathologist.

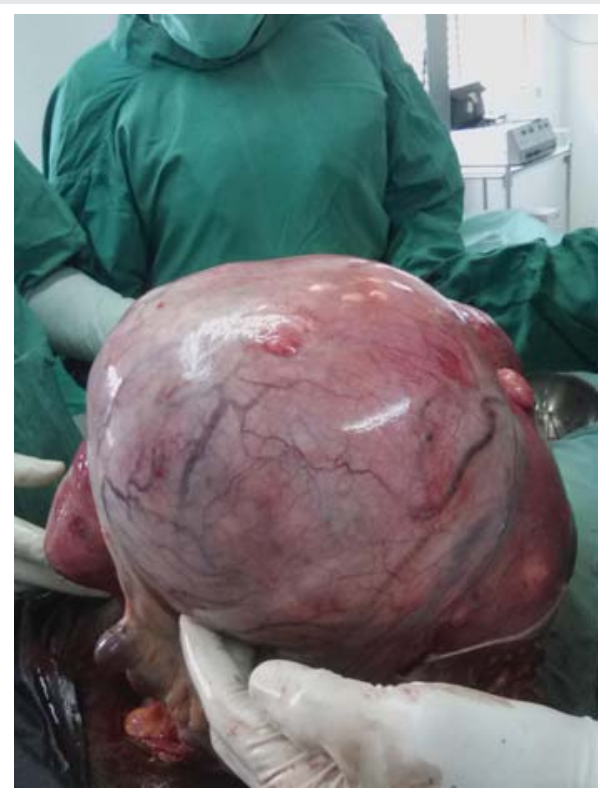

Figure 2: The fibroid masses intraoperatively.

\section{Discussion}

Giant uterine fibroids are uncommon benign neoplasms that typically originate from the myometrium $[1,2]$. They are an uncommon gynaecological problem among women of reproductive age, and their presence can impact negatively on long-term health. Until now less than 100 cases of giant uterine fibroid have been documented worldwide [2].

Uterine fibroids are clinically apparent in $20 \%-30 \%$ of women of reproductive age and may be present in as many as $70 \%$ of uteri removed at hysterectomy [3]. It is estimated that by their fifth decade, as many as $50 \%$ of women of African descent will have leiomyoma [4]. The incidence is decreased with prolonged use of the oral contraceptive pill as well as increasing numbers of term pregnancies.

Uterine fibroids are described as giant when the fibroid tissues weigh more than $11.4 \mathrm{~kg}$ or have a diameter more than $17 \mathrm{~cm}$ or dimension of $33 \times 28 \times 22 \mathrm{~cm}$ [5]. Giant fibroids are potentially life threatening, because they can exert a pressure effect on the surrounding organs, especially the heart and lungs. They are more common in nulliparous women with poor health-seeking attitudes, and they are 2-3 times more prevalent in black women compared with Caucasian, Hispanic or Asian women [3]. Mrs C. E was a black African, and nulliparous.

The etiology of uterine fibroids remains unknown. The main hormones implicated in the growth of fibroid are ovarian steroids (estradiol and progesterone), and the populations of receptors to these hormones are increased in fibroids [2]. Progesterone down-regulates apoptosis in a tumour while estrogen increases the production of extracellular matrix. Cytogenic abnormalities occur in 50\% of fibroids, involving most commonly translocation within or deletion of chromosome [7], translocations of chromosomes 12 and 14 and occasionally, structural aberrations of chromosome [6]. In addition, mutations in the gene encoding fumarate hydratase were shown to predispose women to multiple fibroids [2].

Clinically, they present with grossly distended abdomen and pressure symptoms, such as a sensation of bloating, increased urinary frequency, respiratory difficulty [3] and bowel disturbances. 6 Giant fibroids distend the abdomen with a feeling of dragging(of the abdomen), which may be aesthetically displeasing to many women as was seen in Mrs C. E, who felt embarrassed by her increased abdominal girth. Due to distension of the anterior abdominal wall and the large volume of the abdominal cavity as uterine fibroids can grow into extremely large sizes [7].

Surgical options for the management of giant uterine fibroids include: myomectomy, and abdominal hysterectomy [8]. The main indication for myomectomy is the preservation of the uterus for childbearing in a younger-aged woman [8]. Abdominal hysterectomy is, however, the most effective surgical treatment for giant uterine fibroids, but when giant fibroids are pedunculated, or when fertility is an issue, possible uterine-sparing surgery should be discussed with the patient. Mrs C.E consented for a hysterectomy.

Although uncommon, abdominal hysterectomy can be associated with both short-term and long-term complications. Short-term complications include: excess bleeding, visceral damage and infection. These were absent in Mrs C. E case, because of the precautions taken pre-, intra- and postoperatively to minimize blood loss, infection, tissue damage and adhesions. Furthermore, minimal tissue handling, a short duration of surgery, use of post-operative antibiotics, peritoneal lavage with warm normal saline and good haemostasis after 
the surgery were additional precautions taken to reduce post-operative adhesions, which can complicate abdominal hysterectomy.

\section{Conclusion}

In conclusion, giant fibroids are rarely found in modern times, but they do pose a management challenge. Grossly distended abdomen in a woman of reproductive age with no evidence of malignancy is the most obvious symptoms of a giant uterine fibroid mass. When found, giant fibroids can be a life threatening condition, if they are not managed promptly. This is due mainly to their pressure effects on surrounding organs [4]. The case presented had a successful outcome following expert management.

\section{References}

1. Hoffman BL, Schorge JO, Schaffer JI, Halvorson LM, Bradshaw KD (2012) Cunningham FG (eds.) Pelvic Mass. In: Williams Gynaecology. $2^{\text {nd }}$ ed. McGraw-Hill, USA $247-280$
2. Kalyan S, Sharma S (2018) Giant uterine leiomyoma: a case report with literature review. Int J Reprod Contracept Obstet Gynecol. 7: 4779-4785. Link: http://bit.ly/32MuziG

3. Khaund A, Lumsden MA (2012) Benign diseases of the uterus. In: Edmonds DK (Ed) Dewhurst's textbook of obstetrics and gynaecology. $8^{\text {th }}$ ed.WileyBlackwell publication Ltd 54: 715-728.

4. Steward RG, Denhartog HW, Katz AR (2011) Giant uterine leiomomata. Fertil Steril 95: 1121.e15- e17. Link: http://bit.ly/2TDw12G

5. Wronski K (2014) Giant uterine leiomyoma- case report and review of literature New Med 3: 89-91. Link: http://bit.ly/2wqxGRh

6. Nappi L, Matteo M, Giardian S, Rosenberg P, Indraccolo U, et al. (2008) Management of uterine giant myoma. Arch Gynecol Obs 278: 61-63. Link: http://bit.ly/2vFQImL

7. Ezugwu EC, yoke CA, Ezugwu FO, Ugwu G (2014) Successful pregnancy following myomectomy for giant uterine fibroid in an infertile woman. J Reprod Infertil 15: 233-236. Link: http://bit.ly/38IYclT

8. Garba I, Ayyuba R, Adewale TM, Aburbakar IS (2016) Surgical management of Uterine fibroid in Amino Kano teaching hospital. Niger J Basic Clin Sci 13 50-54. Link: http://bit.ly/3806IXP

\section{Discover a bigger Impact and Visibility of your article publication with}

\section{Peertechz Publications}

\section{Highlights}

* Signatory publisher of ORCID

* Signatory Publisher of DORA (San Francisco Declaration on Research Assessment)

* Articles archived in worlds' renowned service providers such as Portico, CNKI, AGRIS, TDNet, Base (Bielefeld University Library), CrossRef, Scilit, J-Gate etc.

* Journals indexed in ICMJE, SHERPA/ROMEO, Google Scholar etc.

* OAI-PMH (Open Archives Initiative Protocol for Metadata Harvesting)

* Dedicated Editorial Board for every journal

* Accurate and rapid peer-review process

* Increased citations of published articles through promotions

* Reduced timeline for article publication

Submit your articles and experience a new surge in publication services (https://www.peertechz.com/submission).

Peertechz journals wishes everlasting success in your every endeavours.

Copyright: (c) 2020 Nnaji HC, et al. This is an open-access article distributed under the terms of the Creative Commons Attribution License, which permits unrestricted use, distribution, and r eproduction in any medium, provided the original author and source are credited. 